\title{
Toxoplasma gondii antibodies in wild rodents and marsupials from the Atlantic Forest, state of Sáo Paulo, Brazil
}

Anticorpos contra Toxoplasma gondii em roedores e marsupiais da Mata Atlântica, estado de São Paulo, Brasil

Solange Maria Gennari ${ }^{1 *}$; Maria Halina Ogrzewalska²; Herbert Sousa Soares ${ }^{1}$; Danilo Gonçalves Saraiva ${ }^{1}$; Adriano Pinter ${ }^{3}$; Fernanda Aparecida Nieri-Bastos ${ }^{1}$; Marcelo Bahia Labruna'; Matias Pablo Juan Szabó ${ }^{4}$;

Jitender Prakash Dubey ${ }^{5}$

\author{
'Departamento de Medicina Veterinária Preventiva e Saúde Animal, Faculdade de Medicina Veterinária e Zootecnia, \\ Universidade de São Paulo - USP, São Paulo, SP, Brasil \\ ${ }^{2}$ Laboratório de Hantaviroses e Rickettsioses, Instituto Oswaldo Cruz, Fundação Oswaldo Cruz - FIOCRUZ, \\ Rio de Janeiro, RJ, Brasil \\ ${ }^{3}$ Superintendência de Controle de Endemias, São Paulo, SP, Brasil \\ ${ }^{4}$ Faculdade de Medicina Veterinária, Universidade Federal de Uberlandia - UFU, Uberlandia, MG, Brasil \\ ${ }^{5}$ Animal Parasitic Diseases Laboratory, Beltsville Agriculture Research Center, Agricultural Research Service, \\ United States Department of Agriculture, Beltsville, MD, USA
}

Received January 28, 2015

Accepted March 27, 2015

\begin{abstract}
Toxoplasma gondii is a protozoan parasite that infects a large spectrum of warm-blooded animals, including humans. Small rodents and marsupials play an important role in the epidemiology of $T$. gondii because they are sources of infection for domestic and feral cats. Serum samples from 151 rodents and 48 marsupials, captured in the Atlantic Forest, São Paulo State, southeastern Brazil, were analyzed for the presence of T. gondii antibodies. Antibodies detected by the modified agglutination test (MAT $\geq 25)$ were found in $8.6 \%(13 / 151)$ of the rodents and $10.4 \%(5 / 48)$ of the marsupials, with titers ranging from 25 to 6400 and from 25 to 3200 , respectively for the rodents and marsupials. Three of the eight species of rodents (Akodon spp., Oligoryzomys nigripes and Rattus norvegicus), and one from the four marsupial species (Didelphis aurita) presented positive animals. T. gondii was described for the first time in the rodent Oligoryzomys nigripes.

Keywords: Atlantic Forest, Brazil, marsupials, rodents, Toxoplasma gondii.
\end{abstract}

\section{Resumo}

Toxoplasma gondii é um protozoário parasita que infecta animais de sangue quente, incluindo seres humanos. Pequenos roedores e marsupiais têm papel importante na epidemiologia do T. gondii, pois são fontes de infecção para os felídeos domésticos e selvagens. Amostras de soro de 151 roedores e 48 marsupiais, capturados na Mata Atlântica, Estado de São Paulo, Sudeste do Brasil, foram analisadas para a pesquisa de anticorpos anti-T. gondii. Os anticorpos foram detectados pelo Teste de Aglutinaçáo Modificada (MAT $\geq 25$ ), com 8,6\% (13/151) dos roedores e 10,4\% (5/48) dos marsupiais soropositivos, com títulos variando de 25 a 6.400 e de 25 a 3.200, respectivamente, para os roedores e os marsupiais. Três das oito espécies de roedores (Akodon spp., Oligoryzomys nigripes e Rattus norvegicus) e uma das quatro espécies de marsupiais (Didelphis aurita) apresentaram animais positivos. A presença de anticorpos anti-T. gondii foi descrita pela primeira vez no roedor Oligoryzomys nigripes.

Palavras-chave: Mata Atlântica, Brasil, marsupiais, roedores, Toxoplasma gondii.

\footnotetext{
*Corresponding author: Solange Maria Gennari. Departamento de Medicina Veterinária Preventiva e Saúde Animal, Faculdade de Medicina Veterinária e Zootecnia, Universidade de São Paulo - USP, Avenida Prof. Orlando Marques de Paiva, 87, Cidade Universitária, CEP 05508-270, São Paulo, SP, Brasil. e-mail: sgennari@usp.br
} 


\section{Introduction}

Toxoplasma gondii is a protozoan parasite that infects a large spectrum of warm-blooded animals, including humans (DUBEY, 2010). Rodents play an important role in the life cycle of $T$. gondii because they are one of the important sources of infection for domestic and feral cats. Studies of cat predation on wildlife suggest that rodents comprise about two-thirds of the prey consumed, although this may vary according to the season, rodent abundance, and the availability of other prey (MARSHALL et al., 2004). Antibodies to T. gondii in small wild rodents from Brazil were reported in Proechimys sp., Rattus rattus, Nectomys rattus, Akodon cursor, and Thrichomys laurentius (COSTA et al., 2012; SIQUEIRA et al., 2013). In urban area $R$. rattus presented antibodies to $T$. gondii (FERRARONI \& MARZOCHI, 1980; COLA et al., 2010), and viable parasites were isolated by bioassay and detected by PCR in Rattus norvegicus and Mus musculus (MURADIAN et al., 2012).

Marsupials in Americas are considered resistant to clinical toxoplasmosis (CANFIELD et al., 1990). The occurrence of T. gondii antibodies in marsupials in Brazil were reported in different species of Didelphis and Monodelphis (FERRARONI \& MARZOCHI, 1980; YAI et al., 2003; SIQUEIRA et al., 2013).

The Atlantic Forest is known of its biodiversity. Originally occupied $1,300,000 \mathrm{~km}^{2}$, however, nowadays, only $7 \%$ of this area remained. Despite its devastation, the Atlantic Forest is a rich biome with about 850 species of birds and 270 species of mammals (Brasil, 2014). This study aims to investigate the occurrence of anti-T. gondii antibodies in wild rodents and marsupials captured in the Atlantic Forest, in the state of São Paulo, southeastern region of Brazil.

\section{Material and Methods}

The use of the wild animals was approved by the Brazilian Institute of Natural Resources (IBAMA No.22212-1) and the project was in accordance with the Ethical Principles in Animal Research by Brazilian College of Animal Experimentation.

\section{Study area}

This study encompassed eight localities: three forest areas in the southern part of the São Paulo metropolitan area (SPMA), within the municipalities of São Bernardo do Campo, Diadema and Santo André; three forest areas in the northern part of the SPMA (municipalities of Arujá, Mairiporã and Nazaré Paulista), one forest area (Cantareira State Park) in the northern part of the SPMA, within São Paulo municipality. The detailed description of these areas is found elsewhere (OGRZEWALSKA et al., 2012). The last area was located in the municipality of Peruíbe, the largest area $(79,830 \mathrm{ha})$ of preserved forest represented by an Ecological Reserve (Estação Ecológica de Juréia-Itatins). The Reserve is located by the seaside, $20 \mathrm{~m}$ above sea level and all other areas are located between 765 and $1000 \mathrm{~m}$ above sea level, and as a Reserve area have a governmental protection and very few contact with humans and domestic animals. All the areas have a subtropical climate (average annual temperature of $18^{\circ} \mathrm{C}$, rain index of $1400 \mathrm{~mm}$ ).

\section{Collection of samples}

Inside the forest fragment the trapped animals were anaesthetized (1 $\mathrm{mL} / \mathrm{Kg}$ ketamine chloride via intramuscular), identified to species (BONVICINO et al., 2008; PAGLIA et al., 2012), submitted to blood collection, marked with metal rings with individual number, and released at the capture site. Blood samples were taken from mandibular (rodents) and tail (marsupials) veins (OGRZEWALSKA et al., 2012). Samples were collected from April 2010 to January 2011.

\section{Diagnostic test}

Sera were tested for the presence of antibodies to T. gondii by modified agglutination test (MAT) as previously described (DUBEY \& DESMONTS, 1987). Sera were screened at 1:25 (SIQUEIRA et al., 2013; YAI et al., 2003) and the positive samples were end titrated using 2-fold serial dilutions.

\section{Results and Discussion}

Samples were obtained from 151 rodents and 48 marsupials, from eight rodent and four marsupial species. The occurrence of T. gondii antibodies was $8.6 \%$ (13/151) for rodents and $10.4 \%$ (5/48) for marsupials. From the rodents, three different species were positive: Akodon spp. (10.5\%, 11/105), Oligoryzomys nigripes (5.5\%, 1/18), Rattus norvegicus (100\%, 1/1), and from the marsupials only the species Didelphis aurita had T. gondii antibodies (12.5\%, 5/40). Rodents were captured in all investigated areas, however, the positive animals were only found in the Municipality of Arujá (5.5\%), Santo André (21.7\%) and São Bernardo do Campo (17.5\%). Marsupials were captured in six investigated areas and positive animals were observed in Municipality of Diadema (25\%), São Bernardo do Campo (16.6\%) and São Paulo (60\%). Table 1 presents the occurrence of antibodies to T. gondii per rodent and marsupial species per municipality.

Antibody titers ranged from 25 to 6400 for the rodents and from 25 to 3200 for the marsupials (Table 2).

The occurrence of T. gondii antibodies in marsupials in Brazil were also previously reported in Didelphis marsupialis and Didelphis albiventris, captured in the Brazilian Savanna (YAI et al., 2003), and in Didelphis aurita, Monodelphis domestica, Metachirus nudicaudatus, Marmosa murina, Marmosa demerarae and Marmosa sp. collected in northeastern region of the Atlantic Forest, in the state of Pernambuco (FERRARONI \& MARZOCHI, 1980; SIQUEIRA et al., 2013).

Toxoplasma gondii antibodies are reported here for the first time in the rodent Oligoryzomys nigripes. This species is abundant in the Atlantic Forest and Araucaria forest areas throughout Southern Brazil and the Southern part of the gallery forests of the Cerrado, extending to the Pampas on the southern edge of Brazil. This species has a generalist habit being found within 
Table 1. Occurrence (\%) (examined/positive) of anti-Toxoplasma gondii antibodies in rodent and marsupial species per municipality. State of São Paulo, 2010-2011, Brazil.

\begin{tabular}{|c|c|c|c|c|c|c|c|c|c|}
\hline \multirow[b]{2}{*}{ SPECIES } & \multicolumn{9}{|c|}{ MUNICIPALITIES \% } \\
\hline & $\begin{array}{l}\text { S. B. do } \\
\text { Campo }\end{array}$ & Diadema & $\begin{array}{l}\text { Santo } \\
\text { André }\end{array}$ & Arujá & Mairiporá & $\begin{array}{l}\text { Nazaré } \\
\text { Paulista }\end{array}$ & Sáo Paulo & Peruíbe & $\begin{array}{c}\text { (Total/ } \\
\text { Positive) }\end{array}$ \\
\hline \multicolumn{10}{|l|}{ RODENTS } \\
\hline Akodon spp. & $17.6(34 / 6)$ & $(8 / 0)$ & $22.2(18 / 4)$ & $7.6(13 / 1)$ & $(6 / 0)$ & $(6 / 0)$ & $(12 / 0)$ & $(8 / 0)$ & $10.5(105 / 11)$ \\
\hline Oligoryzomys nigripes & $16.6(6 / 1)$ & $(4 / 0)$ & $(4 / 0)$ & $(2 / 0)$ & 0 & 0 & $(2 / 0)$ & 0 & $5.5(18 / 1)$ \\
\hline Oecomys spp. & 0 & 0 & 0 & 0 & 0 & 0 & 0 & $(1 / 0)$ & $(1 / 0)$ \\
\hline Oxymycterus spp. & 0 & 0 & 0 & 0 & 0 & 0 & 0 & $(2 / 0)$ & $(2 / 0)$ \\
\hline Euryoryzomys russatus & 0 & 0 & 0 & $(2 / 0)$ & 0 & $(1 / 0)$ & $(2 / 0)$ & $(17 / 0)$ & $(22 / 0)$ \\
\hline $\begin{array}{l}\text { Hylaeamys } \\
\text { megacephalus }\end{array}$ & 0 & 0 & 0 & $(1 / 0)$ & 0 & 0 & 0 & 0 & $(1 / 0)$ \\
\hline Rattus norvegicus & 0 & 0 & $100(1 / 1)$ & 0 & 0 & 0 & 0 & 0 & $100(1 / 1)$ \\
\hline $\begin{array}{l}\text { Nectomys } \\
\text { squamipes }\end{array}$ & 0 & 0 & 0 & 0 & 0 & 0 & $(1 / 0)$ & 0 & $(1 / 0)$ \\
\hline TOTAL & $17.5(40 / 7)$ & $(12 / 0)$ & $21.7(23 / 5)$ & $5.5(18 / 1)$ & $(6 / 0)$ & $(7 / 0)$ & $(17 / 0)$ & $(28 / 0)$ & $8.6(151 / 13)$ \\
\hline \multicolumn{10}{|l|}{ MARSUPIALS } \\
\hline Didelphis aurita & $16.6(6 / 1)$ & $(4 / 1)$ & $(3 / 0)$ & 0 & $(5 / 0)$ & 0 & $60(5 / 3)$ & $(17 / 0)$ & $12.5(40 / 5)$ \\
\hline Monodelphis spp. & 0 & 0 & 0 & 0 & 0 & 0 & 0 & $(3 / 0)$ & $(3 / 0)$ \\
\hline $\begin{array}{l}\text { Metachirus } \\
\text { nudicaudatus }\end{array}$ & 0 & 0 & 0 & 0 & 0 & 0 & 0 & $(3 / 0)$ & $(3 / 0)$ \\
\hline $\begin{array}{l}\text { Micoureus } \\
\text { demerarae }\end{array}$ & 0 & 0 & 0 & 0 & 0 & 0 & 0 & $(2 / 0)$ & $(2 / 0)$ \\
\hline TOTAL & $16.6(6 / 1)$ & $25(4 / 1)$ & $(3 / 0)$ & $(0 / 0)$ & $(5 / 0)$ & 0 & $60(5 / 3)$ & $(25 / 0)$ & $10.4(48 / 5)$ \\
\hline
\end{tabular}

Table 2. Occurrence of antibodies to Toxoplasma gondii and antibody titer in rodent and marsupial species. São Paulo state, 2010-2011, Brazil.

\begin{tabular}{|c|c|c|c|c|}
\hline Species & Tested & Positive & $\%$ & MAT titer (No. positives) \\
\hline \multicolumn{5}{|l|}{ RODENTS } \\
\hline Akodon spp. & 105 & 12 & 11.4 & 25 (8), 50 (1), $100(1), 1600(1), 6400(1)$ \\
\hline Oligoryzomys nigripes & 18 & 1 & 5.5 & $25(1)$ \\
\hline Oecomys spp. & 1 & 0 & * & * \\
\hline Oxymycterus spp. & 2 & 0 & * & * \\
\hline Euryoryzomys russatus & 22 & 0 & * & * \\
\hline Hylaeamys megacephalus & 1 & 0 & * & * \\
\hline Rattus norvegicus & 1 & 1 & 100.0 & $100(1)$ \\
\hline Nectomys squamipes & 1 & 0 & * & * \\
\hline \multicolumn{5}{|l|}{ MARSUPIALS } \\
\hline Didelphis aurita & 40 & 5 & 12.5 & $25(2), 50(1), 200(1), 3200(1)$ \\
\hline Monodelphis spp. & 3 & 0 & * & * \\
\hline Metachirus nudicaudatus & 3 & 0 & * & * \\
\hline Micoureus demerarae & 2 & 0 & * & * \\
\hline Total & 199 & 19 & 9.5 & \\
\hline
\end{tabular}

*Negative.

forests and open vegetation formations and has a great capacity for adaptation to anthropic environments, including agricultural areas dwellings and barns entering in contact with domestic animals (PÜTTKER et al., 2008; DALMAGRO \& VIEIRA, 2005) which make this specie important in the epidemiology of T. gondii.

Although $52 \%$ of all marsupials represented by all four species were captured in the Ecological Reserve, at Peruíbe, none had antibodies to T. gondii. Similar results were observed for the rodents, with all the 25 rodents from the Reserve been seronegative to $T$. gondii. In the Reserve exist various species of wild cats, Leopardus pardalis,
Puma concolor, Panthera onca, Felis pardalis, Puma yagouaroundi (PARDINI \& DEVELEY, 2004; MARTINS et al., 2008), that might play role in the zoonotic cycle of $T$. gondii being the define host, as suggested by Cañón-Franco et al. (2013). However the absence of positive animals indicate that this environment is on equilibrium and emphasizes the importance of the anthropogenic pressure on the Atlantic rainforest, since all positive animals were captured on areas under high anthropogenic effect, where interactions between small mammals and domestic cats are easily observed. Such impact should be further investigated. 


\section{References}

Bonvicino CR, Oliveira JA, D'Andrea PS. Guia dos roedores do Brasil: com chaves para os gêneros baseadas em caracteres externos. Rio de Janeiro: Centro Pan-Americano da Saúde; 2008.

Brasil. Ministério do Meio Ambiente. Mata Atlântica [online]. 2014 [cited 2014 Nov 25]. Available from: http://www.mma.gov.br/biomas/ mata-atlantica/

Canfield PJ, Hartley WJ, Dubey JP. Lesions of toxoplasmosis in Australian marsupials. J Comp Pathol 1990; 103(2): 159-167. http://dx.doi. org/10.1016/S0021-9975(08)80172-7. PMid:2246391.

Cañón-Franco WA, Araújo FAP, López-Orozco N, Jardim MMA, Keid LB, Dalla-Rosa C, et al. Toxoplasma gondii in free-ranging wild small felids from Brazil: molecular detection and genotypic characterization. Vet Parasitol 2013; 197(3-4): 462-469. http://dx.doi.org/10.1016/j. vetpar.2013.07.019. PMid:23932730.

Cola GA, Garcia JL, da Costa L, Ruffolo B, Navarro IT, Freire RL. Comparação da reação de imunofluorescência indireta e teste de aglutinação modificado na detecção de anticorpos anti-Toxoplasma gondii em ratos. Semina: Ciênc Agrár 2010; 31(3): 717-722. http://dx.doi. org/10.5433/1679-0359.2010v31n3p717.

Costa DGC, Marvulo MFV, Silva JSA, Santana SC, Magalhães FJR, Lima CD Fo, et al. Seroprevalence of Toxoplasma gondii in domestic and wild animals from the Fernando de Noronha, Brazil. J Parasitol 2012; 98(3): 679-680. http://dx.doi.org/10.1645/GE-2910.1. PMid:22150091.

Dalmagro AD, Vieira EM. Patterns of habitat utilization of small rodents in an area of Araucaria forest in Southern Brazil. Austral Ecol 2005; 30(4): 353-362. http://dx.doi.org/10.1111/j.1442-9993.2005.01447.x.

Dubey JP, Desmonts G. Serological responses of equids fed Toxoplasma gondii oocysts. Equine Vet J 1987; 19(4): 337-339. http://dx.doi. org/10.1111/j.2042-3306.1987.tb01426.x. PMid:3622463.

Dubey JP. Toxoplasmosis of animals and humans. 2nd ed. Boca Raton, FL: CRC Press; 2010.

Ferraroni JJ, Marzochi MCA. Prevalência da infecção pelo Toxoplasma gondii em animais domésticos, silvestres e grupamentos humanos da Amazônia. Mem Inst Oswaldo Cruz 1980; 75(1-2): 99-109. http://dx.doi. org/10.1590/S0074-02761980000100010. PMid:7231162.
Marshall PA, Hughes JM, Williams RH, Smith JE, Murphy RG, Hide G. Detection of high levels of congenital transmission of Toxoplasma gondii in natural urban populations of Mus domesticus. Parasitology 2004; 128(1): 39-42. http://dx.doi.org/10.1017/S0031182003004189. PMid:15002902.

Martins R, Quadros J, Mazzolli M. Hábito alimentar e interferência antrópica na atividade de marcação territorial do Puma concolor e Leopardus pardalis (Carnivora: Felidae) e outros carnívoros na Estação Ecológica de Juréia-Itatins, São Paulo, Brasil. Rev Bras Zool 2008; 25(3): 427-435. http://dx.doi.org/10.1590/S0101-81752008000300007.

Muradian V, Ferreira LR, Lopes EG, Esmerini PO, Pena HFJ, Soares RM, et al. A survey of Neospora caninum and Toxoplasma gondii infection in urban rodents from Brazil. J Parasitol 2012; 98(1): 128-134. http:// dx.doi.org/10.1645/GE-2817.1. PMid:21790367.

Ogrzewalska M, Saraiva DG, Moraes J Fo, Martins TF, Costa FB, Pinter A, et al. Epidemiology of brazilian spotted fever in the Atlantic Forest, state of São Paulo, Brazil. Parasitology 2012; 139(10): 1283-1300. http:// dx.doi.org/10.1017/S0031182012000546. PMid:22716923.

Paglia AP, Fonseca GAB, Rylands AB, Herrmann G, Aguiar LMS, Chiarello AG, et al. Annotated checklist of brazilian mammals. 2nd ed. Arlington, VA: Conservation International; 2012. n. 6. Occasional Papers in Conservation Biology. 76 p.

Pardini R, Develey PF. Mamíferos de médio e grande porte na Estação Ecológica Juréia-Itatins. In: Marques OAV, Duleba W, editors. Estação Ecológica Juréia-Itatins, ambiente físico, flora e fauna. Ribeirão Preto: Holos; 2004. p. 304-331.

Püttker T, Pardini R, Meyer-Lucht Y, Sommer S. Responses of five small mammal species to micro-scale variations in vegetation structure in secondary Atlantic Forest remnants, Brazil. BMC Ecol 2008; 8(1): 9. http://dx.doi.org/10.1186/1472-6785-8-9. PMid:18457587.

Siqueira DB, Aléssio FM, Mauffrey JF, Marvulo MFV, Ribeiro VO, Oliveira RL, et al. Seroprevalence of Toxoplasma gondii in wild marsupials and rodents from the Atlantic forest of Pernambuco state, northeastern region, Brazil. J Parasitol 2013; 99(6): 1140-1143. http://dx.doi.org/10.1645/ GE-2855.1. PMid:23829204.

Yai LEO, Cañon-Franco WA, Geraldi VC, Summa MEL, Camargo MCGO, Dubey JP, et al. Seroprevalence of Neospora caninum and Toxoplasma gondii antibodies in the South American opossum (Didelphis marsupialis) from the city of São Paulo, Brazil. J Parasitol 2003; 89(4): 870-871. http://dx.doi.org/10.1645/GE-83R. PMid:14533710. 